\title{
A study of the morphoanatomical characters of the leaves of Chamaecrista [L.J Moench sect. Apoucouita [Leguminosae-Caesalpinioideae]
}

\author{
Ítalo Antônio Cotta Coutinho', Juliana Gastaldello Rando², Adilva de Souza Conceição ${ }^{3}$ and Renata Maria Strozi \\ Alves Meira ${ }^{*}$
}

Received: February 3, 2016

Accepted: March 7, 2016

\begin{abstract}
Little attention has been paid to species of Chamaecrista sect. Apoucouita (Leguminosae-Caesalpinioideae), especially regarding anatomical studies. When only vegetative material is available, the identification of such species may be difficult. Additionally, vegetative material of some species of $C$. sect. Apoucouita may be even harder to identify because they can resemble species of Inga Mill. (Leguminosae-Mimosoideae). The present study focused on recognizing morphoanatomical characters of leaves that are taxonomically useful for the species of $C$. sect. Apoucouita by employing standard anatomical techniques. The arrangement of the vascular system in the petiole/rachis, dorsiventral mesophyll, mucilage idioblasts in the epidermis of leaflets and hypostomatic leaves were some of the characters shared by all species studied. Length of the petiole, position and type of extrafloral nectaries, leaflet venation, presence and type of papillae on the epidermis of the leaflet blades and sclereids in the mesophyll were some of the characters useful in the distinction of taxa. The vascular arrangement of the petiole/rachis is a promising character in the distinction of species of $C$. sect. Apoucouita and Inga. Based on morphoanatomical data, the taxonomic revision of some species and varieties ascribed to $C$. sect. Apoucouita is suggested.
\end{abstract}

Keywords: Amazon Rainforest, applied botany, Atlantic Forest, extrafloral nectaries, papillae, secretory idioblasts, secretory structures, taxonomy

\section{Introduction}

Chamaecrista is one of the most diverse genera of Leguminosae-Caesalpinioideae, including about 330 species (Lewis 2005). Species of Chamaecrista can be readily recognized by the presence of paripinnate leaves (Fig. 1AC) or less commonly bifoliolate, yellow flowers (Fig. 1D-F), androecium (erratically) actinomorphic, anthers pubescent along the sutures, a pair of bracteoles at the flower pedicel, elastically dehiscent pod with coiling valves (Fig. $1 \mathrm{G}$ ) and either the presence of extrafloral nectaries (Fig. 1A-C) on the leaves or sticky glandular hairs usually all over the plant body (Irwin \& Barneby 1982). Species of Chamaecrista are classified into six sections: $C$. sect. Apoucouita, Absus, Caliciopsis, Chamaecrista, Grimaldia and Xerocalyx.

Chamaecrista sect. Apoucouita, composed of 21 species (26 taxa), contains most of the arborescent species of the genus. Besides including arborescent species (Fig. 1D), C.

\footnotetext{
${ }^{1}$ Anatomia Vegetal, Departamento de Biologia Vegetal, Universidade Federal de Viçosa, Av. P. H. Rolfs, s/n, 36570-900, Viçosa, MG, Brazil ${ }^{2}$ Programa de Pós-Graduação em Ciências Ambientais, Universidade Federal do Oeste da Bahia, Rua Professor José Seabra de Lemos 316, 47808021, Barreiras, BA, Brazil

${ }^{3}$ Herbário HUNEB (Coleção Paulo Afonso), Departamento de Educação, Universidade do Estado da Bahia, Rua da Gangorra 503, 48608-240, Paulo Afonso, BA, Brazil

* Corresponding author: rmeira@ufv.br
} 
Ítalo Antônio Cotta Coutinho, Juliana Gastaldello Rando,

Adilva de Souza Conceição and Renata Maria Strozi Alves Meira
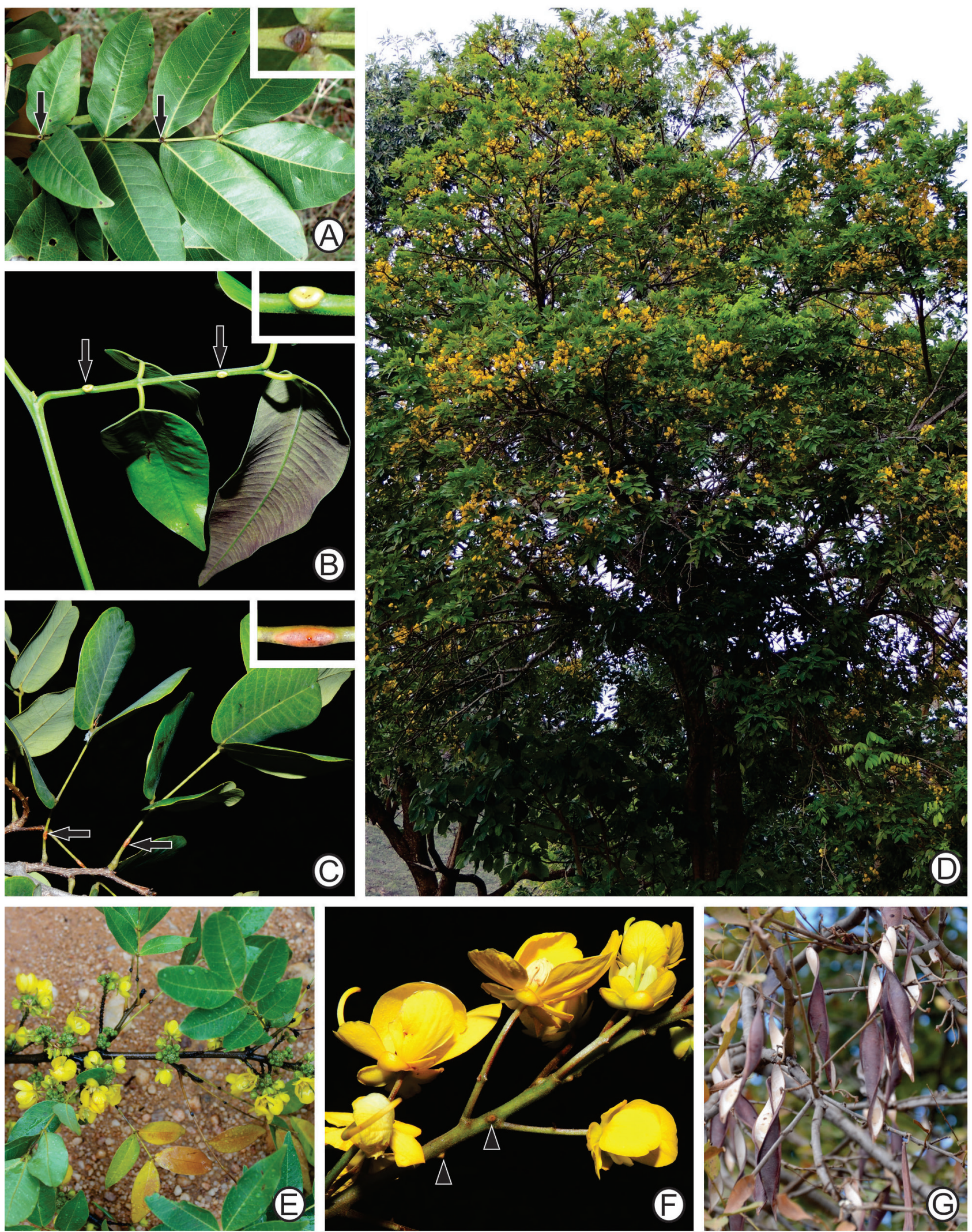

Figure 1. Species of Chamaecrista sect. Apoucouita: Extrafloral nectaries (EFN, arrows) on the petiole/rachis of (A) C. eitenorum var. regana, (B) C. hymenaeifolia and C. polystachya. Note the detail of EFNs in A-C. (D, E) C. ensiformis var. ensiformis. Note the ramiflorous inflorescences in (E); (F) Raceme of $C$. polystachya charged with glands (arrowheads); (G) Pendant elastically dehiscent pods of $C$. ensiformis var. ensiformis. 
sect. Apoucouita may be characterized as having cauliflorous or ramiflorous inflorescences (Fig. 1E) with minute, truncate or depressive inflorescence glands (Fig. 1F) and pendant elastically-dehiscent pods (Fig. 1G). Such arborescent species are usually found in neotropical rain forests, and are most diverse in the Amazon and Brazilian Atlantic forests (Irwin \& Rogers 1967; Irwin \& Barneby 1977; Conceição et al. 2009).

Chamaecrista has received much attention in the last 10 years with studies on their anatomy (Francino et al. 2006; Coutinho et al. 2012; 2013; 2015; Meira et al. 2014), molecular biology (Conceição et al. 2008; 2009; Torres et al. 2011; Rando et al. 2016), taxonomy (Camargo \& Miotto 2004; Dantas \& Silva 2013; Rando et al. 2013), ecology, geography (Rando \& Pirani 2011), and ecological and economic importance (Morris 2012). Little attention, however, has been paid to the species of $C$. sect. Apoucouita, especially regarding their anatomy.

Additionally, non-reproductive individuals of $C$. sect. Apoucouita can be quite difficult to identify since vegetative material may resemble species of the genus Inga, especially because of the winged petiole in some species and the always-present leaf extrafloral nectaries. Morphoanatomical characters have proven to be useful in taxonomic and phylogenetic research of not only Leguminosae (Solereder 1908; Metcalfe \& Chalk 1950; 1979; Lackey 1978; Luckow 2002; Arambarri et al. 2006) but also Chamaecrista (Coutinho et al. 2013; 2015; Francino et al. 2015).

Moreover, the delimitation of the varieties within species of $C$. sect. Apoucouita seems to be rather complex. For instance, varieties of $C$. adiantifolia were once defined based on pubescence and flower size (Irwin \& Rogers 1967), then later on length of pulvinule and shape of the leaflet apex (Irwin \& Barneby 1977). These authors themselves stated that 'the varietal key might be emended as follows, but requires testing against the full range of material available to the taximetric study' (Irwin \& Barneby 1977). Morphoanatomy has proven useful in supporting molecular studies within Chamaecrista, which elevated all varieties to the species level (Conceição et al. 2008; Coutinho et al. 2013).

Owing to the importance of morphoanatomical characters as an additional tool in taxonomic and phylogenetical studies, we addressed the following questions: Are there recognizable leaf morphoanatomical characters that support the taxonomy of the species of $C$. sect. Apoucouita? If so, could such characters be used to build an identification key? Can morphoanatomy support the varieties ascribed to $C$. sect. Apoucouita?

\section{Materials and methods}

We sampled 23 (18 spp.) of the 26 taxa (21 spp.) which belong to C. sect. Apoucouita (Irwin \& Barneby 1982; 1985; Barneby 1999) (S1 in Supplementary Material). Taxonomic authorities for all taxa used in the paper are given in the Supplementary Material. Both field-collected and herbarium material were used. Voucher specimens were deposited at the herbarium of the Universidade Federal de Viçosa (VIC), Universidade de São Paulo (SPF), and Universidade Estadual de Feira de Santana (HUEFS) (acronyms according to Thiers 2016, continuously updated).

Fully expanded leaves were collected in the field and fixed in FAA (formaldehyde, acetic acid and 50\% ethanol; 1:1:18 by volume) for $48 \mathrm{~h}$ and stored in $70 \%$ ethanol (Johansen 1940). Material sampled from herbarium specimens was rehydrated by microwaving in distilled water for $7 \mathrm{~min}$ and left to rest overnight. Rehydrated samples were then treated with $2 \%$ potassium hydroxide for $1-2 \mathrm{~h}$ and dehydrated in an ethanol series and stored in $70 \%$ ethanol (Smith \& Smith 1942). For identification of the venation pattern and stomata types, whole and/or fragments of mature leaflets stored in $70 \%$ ethanol of both field-collected and herbarium material were cleared with $10 \%$ sodium hydroxide and $20 \%$ hypochlorite solutions, stained with diluted fuchsin and mounted in glycerinated gelatin (Johansen 1940).

For structural characterization, fragments from the middle portion of both the leaflet (including the middle vein, margin and area between the margin and the middle vein) and the petiole/rachis (base of the petiole right after the pulvinus and rachis right after the insertion of the first pair of leaflets) were taken. The fragments from both the herbarium and field-collected specimens stored in $70 \%$ ethanol were embedded in methacrylate (Historesin Leica, Leica Microsystems Nussloch GmbH, Heidelberg, Germany) as recommended by the manufacturer. Cross and longitudinal $4 \mu \mathrm{m}$-thick sections were made using an automatic rotary microtome (Leica RM2155, Deerfield, IL, USA), placed on glass slides, stained with toluidine blue at pH 4.4 (O'Brien \& McCully 1981), dried at room temperature and mounted in resin (Permount, Fisher Scientific, NJ, USA).

Both observations and image captures were conducted using an Olympus Optical AX70TRF (Tokyo, Japan) equipped with a U-Photo system and digital camera (AxioCam HRc - Carl Zeiss - Gottingen, Germany). Classification of the venation and stomata types followed Ellis et al. (2009) and Wilkinson (1979), respectively. Types of vascular arrangements of the petiole/rachis followed Howard (1979) and Francino et al. (2015). The types of leaf extrafloral nectaries and their position, as well as data on the morphology of leaves/leaflets (petiole and blade), were taken from the literature (Irwin \& Rogers 1967; Rizzini 1976; Irwin \& Barneby 1977; 1979a; b; 1982; 1985; Barneby 1999; Coutinho \& Meira 2015).

\section{Results}

\section{Petiole/Rachis}

A petiole shorter than $15 \mathrm{~mm}$ was observed in fourteen taxa (Tab. 1), longer than $15 \mathrm{~mm}$ and shorter than $50 \mathrm{~mm}$ in 17 (Tab. 1) and over $50 \mathrm{~mm}$ in C. amorimii only. Petiole/ 


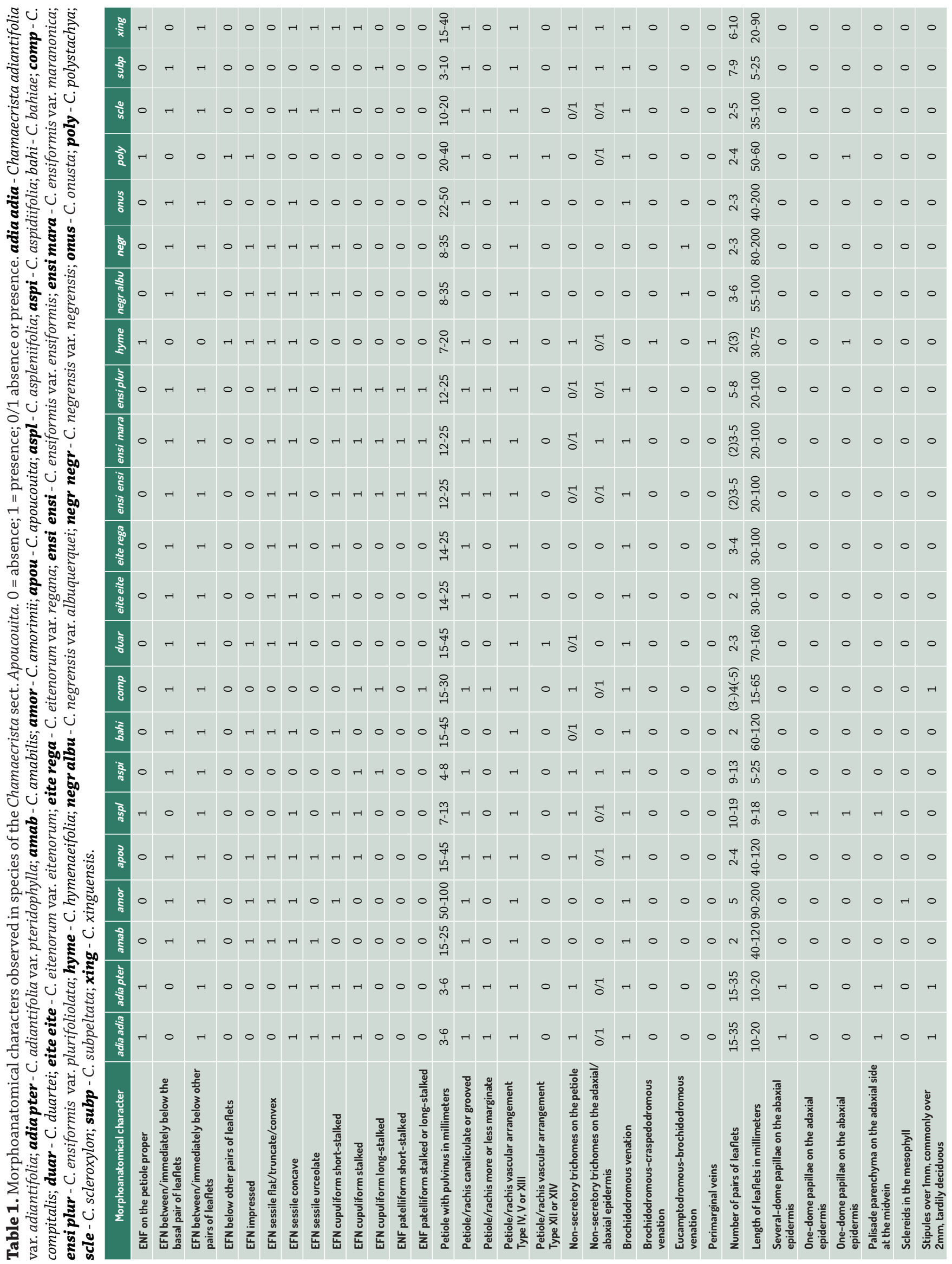


rachis in cross sections varied shape: rounded or slightly angulate, more or less marginate and canaliculate or grooved (Figs. 2, 3). Only four taxa had exclusively rounded or slightly angulate petiole/rachis (i.g. C. bahiae, C. duartei, C. negrensis var. albuquerquei and C. negrensis var. negrensis) (Fig. $2 \mathrm{~A}-\mathrm{B}$, D-E). A canaliculate or grooved petiole/rachis was observed in 19 taxa (Tab. 1), including in C. hymenaeifolia (Fig. 2C), C. apoucouita (Fig. 3B), C. subpeltata (Fig. 3C) and C. adiantifolia var. pteridophylla (Fig. 3E). A more or less marginate petiole/ rachis was observed in eight taxa (Tab. 1), as in C. apoucouita (Fig. 3A), C. adiantifolia var. pteridophylla (Fig. 3D) and C. ensiformis var. ensiformis (Fig. 3F). In C. apoucouita (Fig. $3 \mathrm{~A}$ ) and $C$. scleroxylon, the petiole/rachis was canaliculate or grooved but the most distal segment of the rachis was always marginate (winged). Non-secretory trichomes on the petiole/rachis were found in 15 taxa (Tab. 1), of which six may or may not possess them (C. bahiae, C. duartei, all varieties of $C$. ensiformis and $C$. scleroxylon).

The petiole/rachis of all species studied had the vascular system forming a siphonostele (Figs. 2, 3) made up by a central pith of parenchymatic cells surrounded by layers (three or more) of phloem and xylem, respectively, and then by layers of fibers (Fig. 2A). Sometimes the vascular system did not form concentric layers around the central pith and interruptions were observed as if the siphonostele were incomplete (Figs. 2D, 3E-F). The siphonostele, along with the surrounding layers of fibers, usually displayed a circular or oval shape (Figs. 2A, C-E, 3A-B, D). Occasionally the vascular system appeared more like three interconnected semi-circles (Fig. 2B). The arrangement of the vascular system varied in this manner among and within species.

One or two pairs of accessory bundles on the adaxial side of the petiole were common (Figs. 2B-C, 3A-F), but in rare occasions there could be up to six pairs (Fig. 2A). Such arrangements were consistent with types IV, V and XIII. Type IV was characterized by the presence of a siphonostele and two accessory bundles (Figs. 2B-C, 3B-D). Type V, displayed five or more vascular bundles, consisting of the vascularization of the main petiole and two more accessory bundles, as seen in C. adiantifolia var. pteridophylla (Fig. 3E) and C. ensiformis var. ensiformis. (Fig. 3F). Type XIII had a siphonostele and four-six accessory bundles, as seen in $C$. apoucouita (Fig. 3A).

When the petiole/rachis was winged, the accessory bundles were usually located in the wings (Fig. 3). Apart from the previously mentioned types, $C$. duartei and $C$. polystachya were the only two species that also displayed type XII, with the accessory bundle concentrated at the center of the adaxial side of the petiole (Fig. 2D). As in the previously described types, this arrangement of the vascular system tended to form concentric layers around the central pith, resembling a siphonostele. C. duartei and C. polystachya were also the only species to exhibit a new type of vascular arrangement of the petiole, type XIV (Fig. 2E-F). In this arrangement, the accessory bundles are concentrated at the center of the adaxial side of the petiole; however, the bundles form another cylinder around a less conspicuous central pith (Fig. 2E-F).

Sclereids were encountered in the cortex of the petiole/ rachis of all studied species (Figs. 2A, 3A). Larger leaves had a greater number of sclereids in the cortex of the petiole. Druses were found inside the sclereids and a single-layered sheath of druses was also present encircling the outermost layer of fiber.

\section{Leaflet blade}

The smallest leaflets were found in $C$. adiantifolia, $C$. aspidiifolia, $C$. aspleniifolia and $C$. subpeltata, while the largest were found in C. amorimii, C. duartei, C. negrensis var. negrensis and $C$. onusta (Tab. 1 ). The greatest number of pairs of leaflets was found in C. adiantifolia, C. aspidiifolia and $C$. aspleniifolia, while the other species varied from having 2 to 10 pairs (Tab. 1). All species had entire pinnate leaves with brochidodromous venation (Fig. 4A-B), except for $C$. negrensis, which had eucamptodromous leaves that became brochidodromous distally (resembling the leaf venation of Lauraceae) (Fig. 4C), and C. hymenaeifolia that had craspedodromous-brochidodromous leaves with marginal secondary-type perimarginal veins (Fig. 4D). Marginal ultimate venation was commonly looped (Fig. 4E) for all species, but incomplete marginal ultimate venation (Fig. 4E) was also observed in the same leaflets. Enlarged tracheids (tracheoids) at vein endings were common among all species (Fig. 4F).

Non-secretory trichomes (Fig. 4G-I) were observed on the leaflets in 14 taxa (Tab. 1), of which 10 may or may not have trichomes on leaflets, and when present they were found mainly on the midrib (Fig. 4G) and margins (Fig. 4H-I). Such structures may easily fall off as the leaves grow older. Trichomes were present on all the material collected for only four taxa: C. aspidiifolia, C. ensiformis var. maranonica, C. subpeltata and C. xinguensis.

All species displayed paracytic laterocyclic stomata (Fig. 4J-K) and hypostomatic leaflets; however, we rarely observed few stomata scattered along the midrib on the adaxial side. As a whole, the anticlinal cell walls of epidermal cells on the adaxial side of leaflets were straight or lightly sinuous (Fig. 4L-M) and sinuous on the abaxial side (Fig. $4 \mathrm{~J}-\mathrm{K})$. However, few exceptions could be observed in the collections of the two varieties of $C$. regana and $C$. xinguensis (Fig. $4 \mathrm{~N}$ ) and C. onusta, as sinuosity on the adaxial side could also be observed. Exceptions were also present in a few collections of $C$. amabilis, $C$. amorimii, $C$. bahiae, $C$. compitalis, $C$. ensiformis, $C$. hymenaeifolia, $C$. negrensis, $C$. onusta and $C$. polystachya, as straight anticlinal cell walls of epidermal cells on the abaxial were observed. Leaflet epidermis was single-layered on both the adaxial and the abaxial sides for all species (Fig. 5). 
Ítalo Antônio Cotta Coutinho, Juliana Gastaldello Rando,

Adilva de Souza Conceição and Renata Maria Strozi Alves Meira
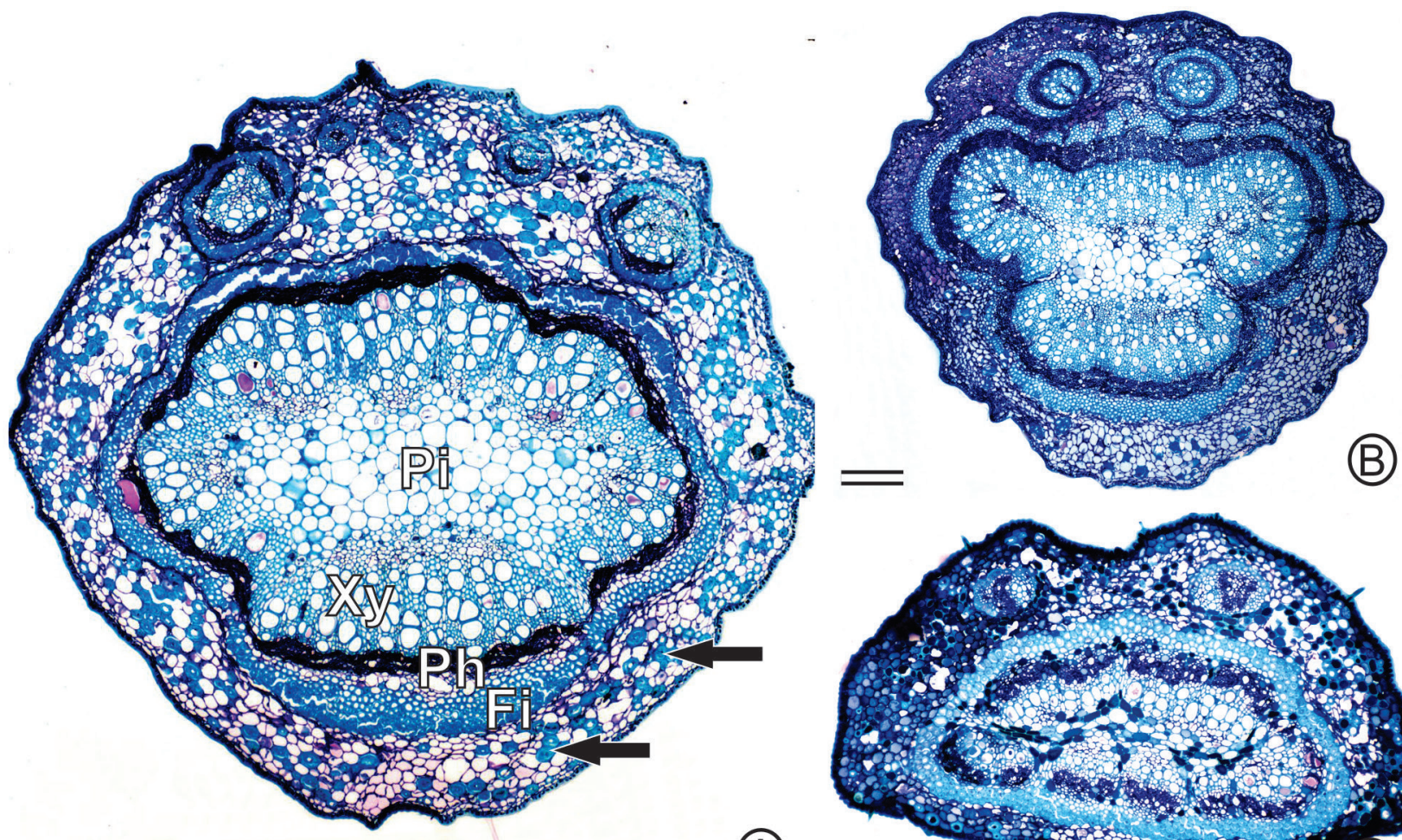

(A)
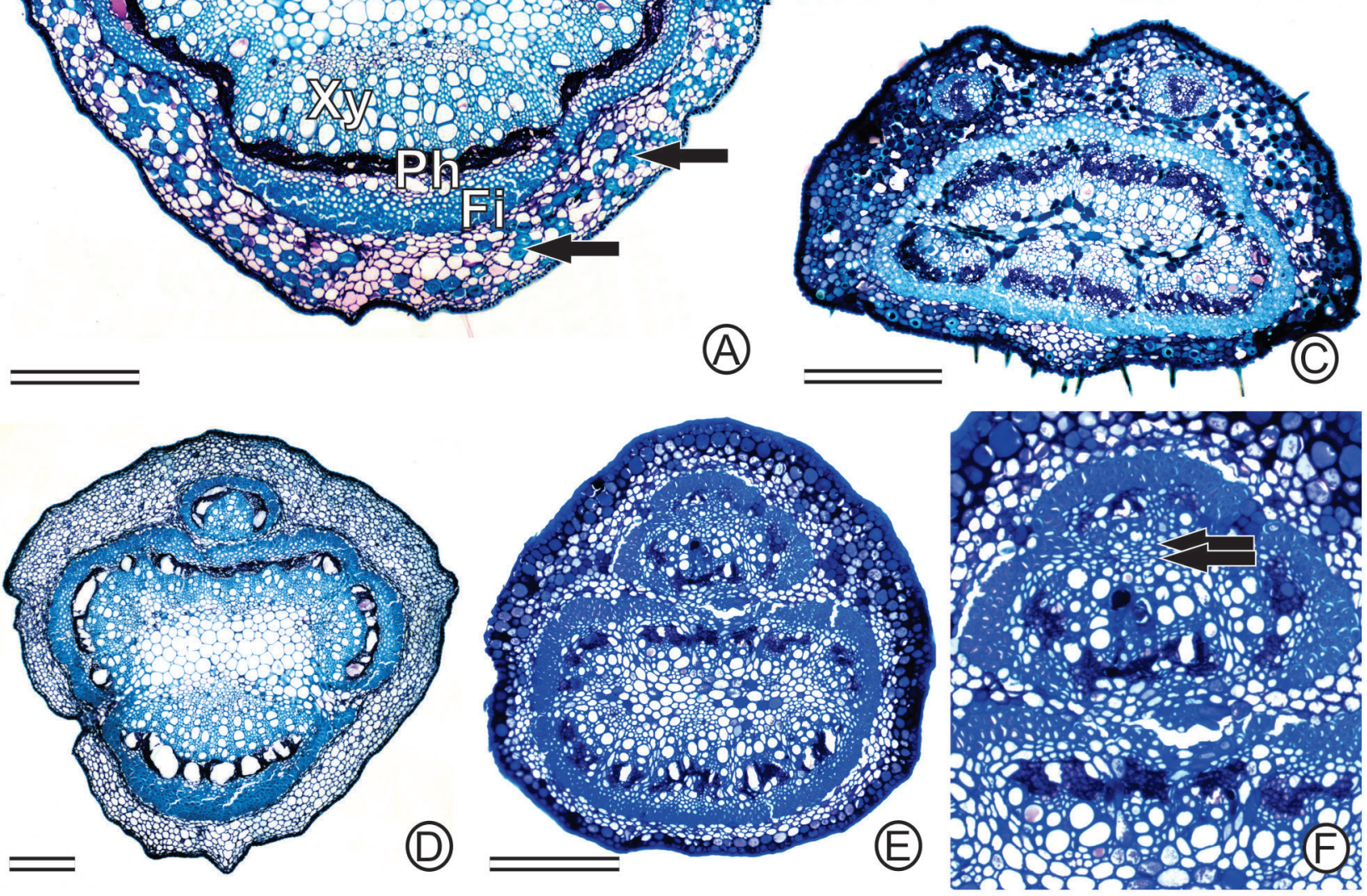

Figure 2. Arrangement of the vascular system forming a siphonostele in cross sections of the petiole/rachis in species of Chamaecrista sect. Apoucouita. (A) C. negrensis var. negrensis. Type XIII of vascular arrangement of the petiole/rachis. Note the presence of sclereids in the cortex (arrows), fibers ( $\mathrm{Fi}$ ) around the main vascular system composed of phloem ( $\mathrm{Ph}$ ) and xylem (Xy) and a central pith (Pi). (B) C. bahiae, type IV. (C) C. hymenaeifolia, type IV, note that the petiole/rachis is grooved. (D) C. duartei, type XII with accessory bundles concentrated at the center of the adaxial side of the petiole/rachis. (E, F) C. polystachya. Type XIV with accessory bundles concentrated at the center of the adaxial side of the petiole, but the bundles form another cylinder around a less conspicuous central pith (double arrows). Bars $=300 \mu \mathrm{m}$.

Papillae (Fig. 6) were observed in only five taxa (Tab. 1). Two different types of papillae were found: several domes per cell (Figs. 5B-C, 6A-C) and one dome per cell (Figs. 5D-E, 6D-E). One-dome papillae were found in C. aspleniifolia (Fig. 5A, F), C. polystachya (Fig. 6D) and C. hymenaeifolia (Fig. $6 \mathrm{E})$, the first species having such papillae on both adaxial and abaxial sides (Fig. 5A, F), while the other two species had one-dome papillae only on the abaxial side (Fig. 5D). Several-dome papillae were found only in the two varieties of $C$. adiantifolia and were always found on the abaxial side (Fig. 5B, C).

Secretory idioblasts (Fig. 5A, B) were observed on the 

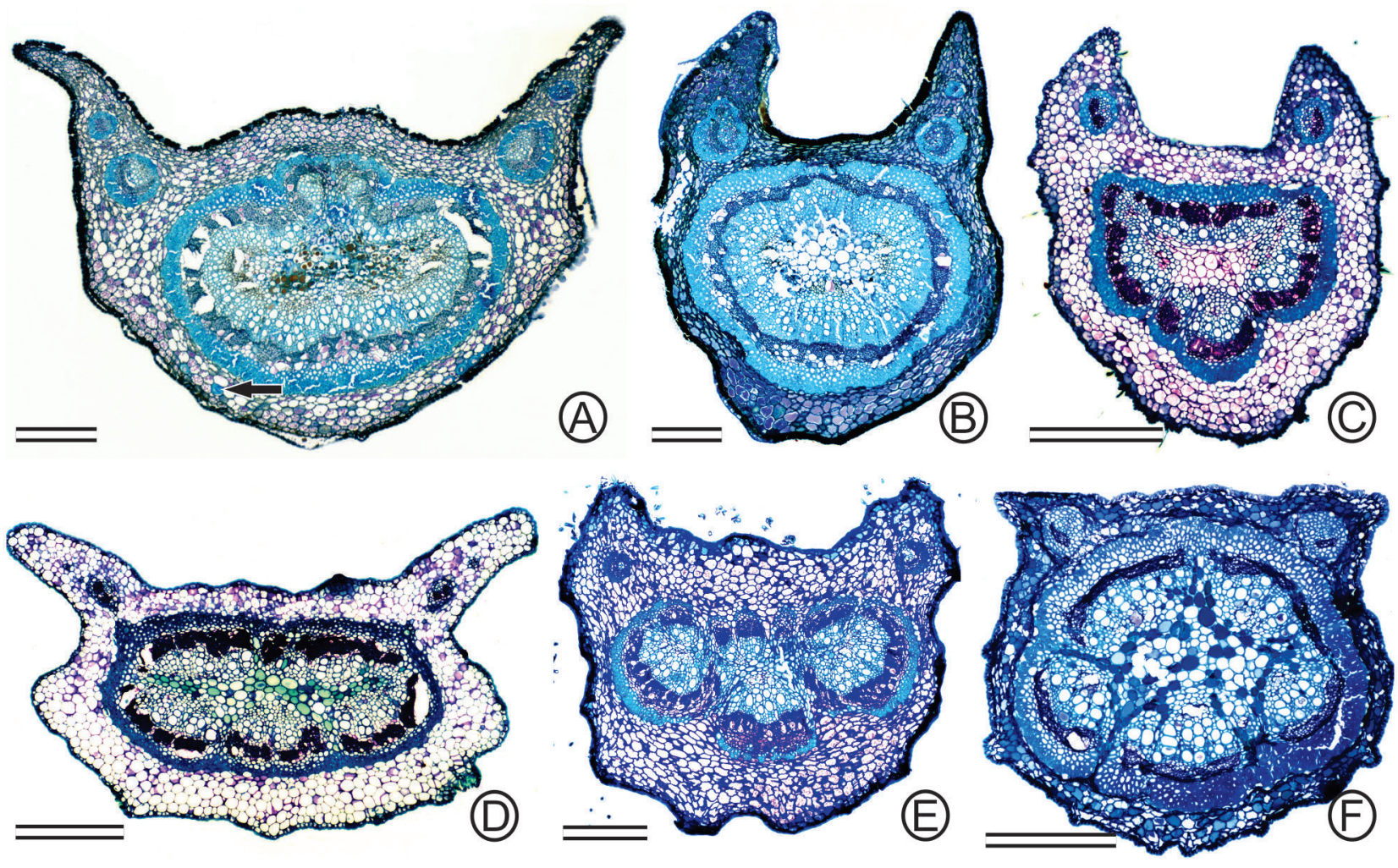

Figure 3. Arrangement of the vascular system in cross sections of the petiole/rachis of species of Chamaecrista sect. Apoucouita. (A, B) C. apoucouita. Arrow indicates sclereids. (C) C. subpeltata. (D, E) C. adiantifolia var. pteridophylla. (F) C. ensiformis var. ensiformis. Note the different types of vascular arrangement of the petiole/rachis. Type XIII in (A), type IV in (B-D) and type V in (E-F). (A, D and F) display petiole/rachis more or less marginate while (B-C and E) canaliculate or grooved. Bars $=300 \mu \mathrm{m}$.

adaxial and abaxial epidermis but were less frequent on the abaxial epidermis, especially when this epidermis had papillae (Fig. 5B). Sometimes the secretory idioblasts displayed a thinner periclinal cell wall, dividing the cell into two, and giving to the epidermis the appearance of a double layer (Fig. 5A, B).

Dorsiventral mesophyll (Fig. 5A-B, E-G) was found in all species. Adaxial palisade parenchyma was composed of 1-3 layers of cells while abaxial spongy parenchyma was composed of 3-12 layers. The number of layers of both palisade and spongy parenchyma varied within species. Sclereids scattered among the mesophyll were exclusive to C. amorimii (Fig. 5E).

Midribs had the vascular system arranged as collateral vascular bundles (Fig. 5A, G-H). Additionally, we observed that some of the samples of every species had collateral vascular bundles with 3-5 accessory bundles on the adaxial side (Fig. 5H). Similar to the vascular system in the petiole, layers of fibers surrounded the vascular system of the midrib. In the area of the midrib, secretory idioblasts in the epidermis were rarely observed (Fig. 5G, H). Layers of collenchyma below the epidermis were followed by layers of chlorenchyma in all species except the two varieties of $C$. adiantifolia and C. aspleniifolia. However, this character was not fixed as sometimes collenchyma was not found and just a few layers of chlorenchyma or parenchyma were present instead. The chlorenchyma on both the adaxial and abaxial side of the midrib could not be classified into palisade or spongy parenchyma since only compact isodiametric cells were found. Only the two varieties of $C$. adiantifolia and $C$. aspleniifolia had palisade parenchyma on the adaxial side of the midrib area (Tab. 1).

\section{Extrafloral Nectaries}

Six taxa exhibited the most basal extrafloral nectary (EFN) exclusively on the petiole proper, such as $C$. hymenaeifolia (Fig. 1B) and C. polystachya (Fig. 1C) (Tab. 1). Seventeen taxa had the most basal EFN between/ immediately below the basal pair of leaflets (Tab. 1), as in C. eitenorum var. regana (Fig. 1A). Other EFNs found on the leaves of all species were located between/immediately below other pairs of leaflets, except in C. hymenaeifolia and C. polystachya were they were located only below the other pairs of leaflets.

Impressed EFNs were observed in nine taxa (Tab. 1), including C. amabilis (Fig. 7A), C. hymenaeifolia (Fig. 7B) and C. polystachya (Fig. 7C); sessile flat/truncate/convex in 13 
Ítalo Antônio Cotta Coutinho, Juliana Gastaldello Rando,

Adilva de Souza Conceição and Renata Maria Strozi Alves Meira
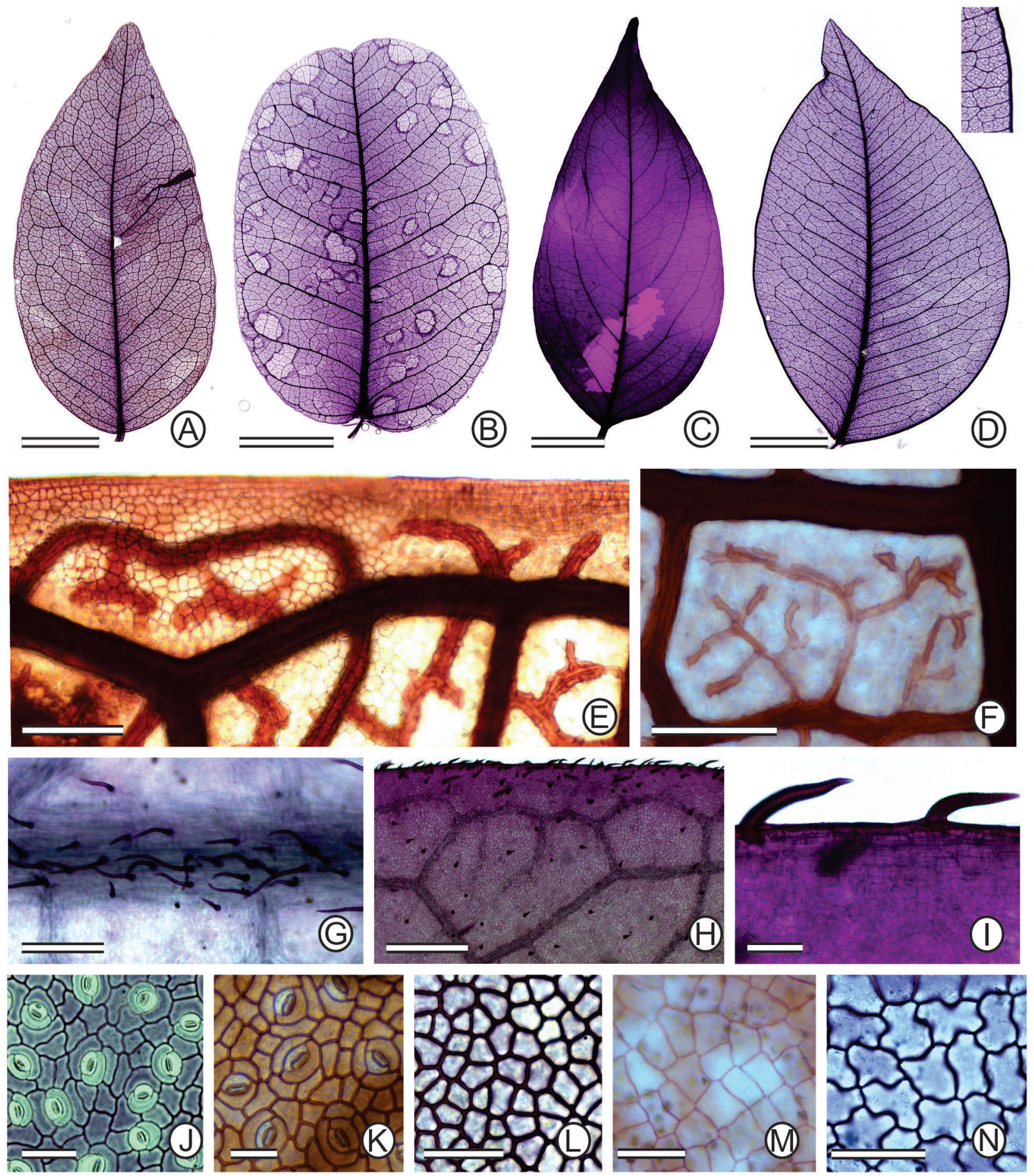

Figure 4. Leaflet clearings of species of Chamaecrista sect. Apoucouita. (A) C. ensiformis var. ensiformis and (B) C. polystachya with brochidodromous venation. (C) C. negrensis var. negrensis with eucamptodromous becoming brochidodromous distally. (D) C. hymenaeifolia with craspedodromous-brochidodromous with detail of the perimarginal veins of marginal secondary type. (E) C. polystachya showing marginal ultimate venation looped and incomplete. (F) C. eitenorum var. eiteronorum with enlarged tracheids (tracheoids) at the vein endings. (G) Non-secretory trichomes on the midvein in C. ensiformis var. maranonica and mostly on the leaflet margin in C. subpeltata $(\mathrm{H}, \mathrm{I}) .(\mathrm{J})$ C. apoucouita and $(\mathrm{K})$ C. amorimii with paracytic laterocyclic stomata on the abaxial side of the epidermis. Note the sinuous outline of anticlinal walls of the epidermal cells on the abaxial side in $(\mathrm{J})$ and straight in $(\mathrm{K})$. (L) C. amorimii and (M) and C. eitenorum var. eitenorum with straight outline of the anticlinal walls of the epidermal cells on the adaxial side and (N) C. xinguensis with sinuous. Bars $=\mathrm{A}-\mathrm{D}, 20 \mathrm{~mm} ; \mathrm{E}-\mathrm{G}, 200 \mu \mathrm{m} ; \mathrm{H}, 500 \mu \mathrm{m}, \mathrm{I}-\mathrm{N}, 50 \mu \mathrm{m}$. 


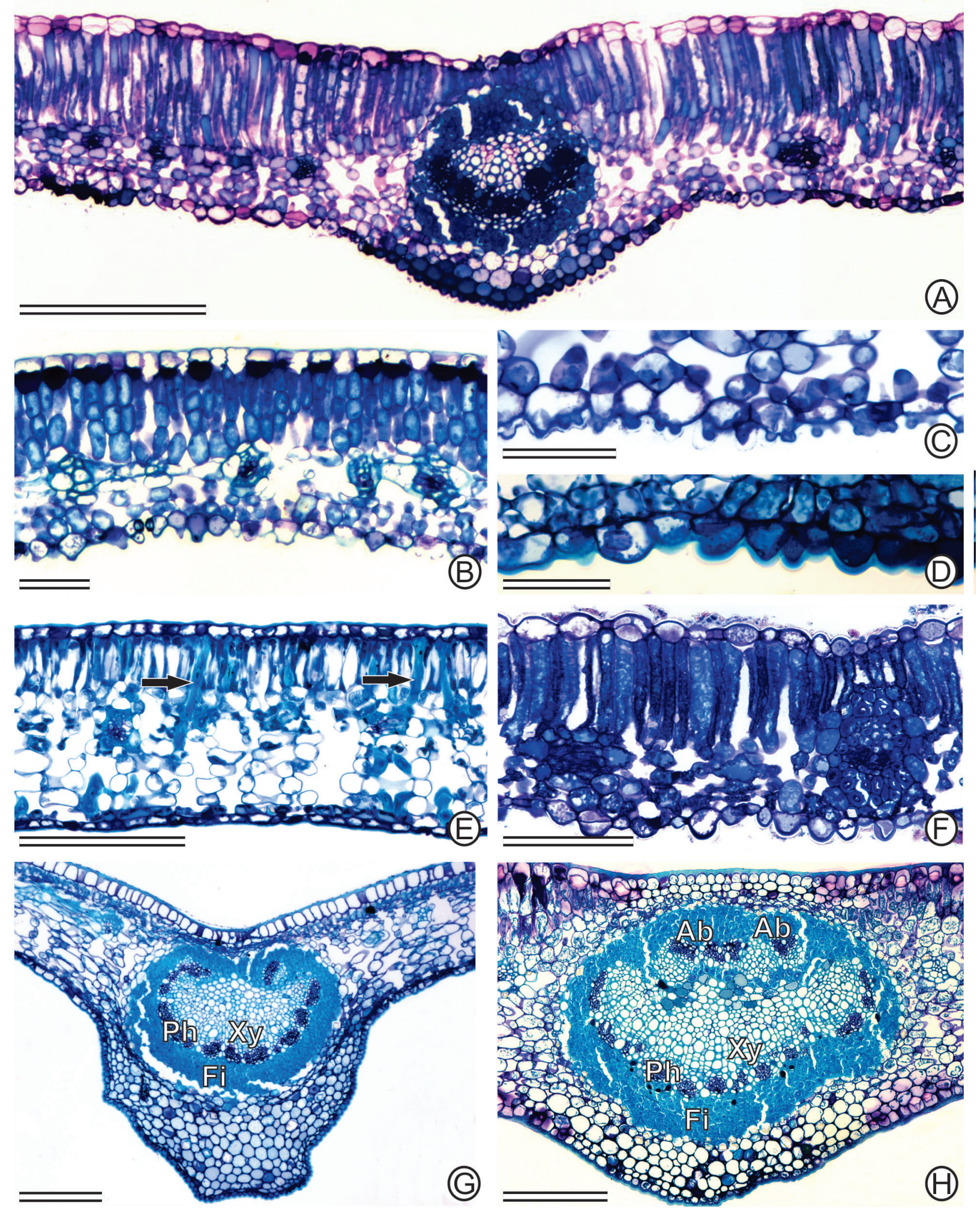

Figure 5. Cross sections of leaflets of species of Chamaecrista sect. Apoucouita. (A) C. aspleniifolia with one-dome papillae on both sides of the epidermis and collateral arrangement of the vascular bundles. (B-C) C. adiantifolia var. pteridophylla with several-dome papillae on the adaxial side of the leaflet. Note mucilage idioblasts in the epidermis.and a thin periclinal cell wall dividing some of the cells into two (B). (D) C. hymenaeifolia with one-dome papillae on the abaxial side. (E) C. amorimii with sclereids (arrows) in the mesophyll. (F) C. aspleniifolia, note epidermis with one-dome papillae on both sides. (G) C. onusta with midvein displaying collateral vascular bundles and $(\mathrm{H})$ C. amabilis with collateral vascular bundles with accessory bundles. Bars = A, E-H, $200 \mu \mathrm{m} ; \mathrm{B}-\mathrm{D}, 50 \mu \mathrm{m}$. 
Ítalo Antônio Cotta Coutinho, Juliana Gastaldello Rando,

Adilva de Souza Conceição and Renata Maria Strozi Alves Meira
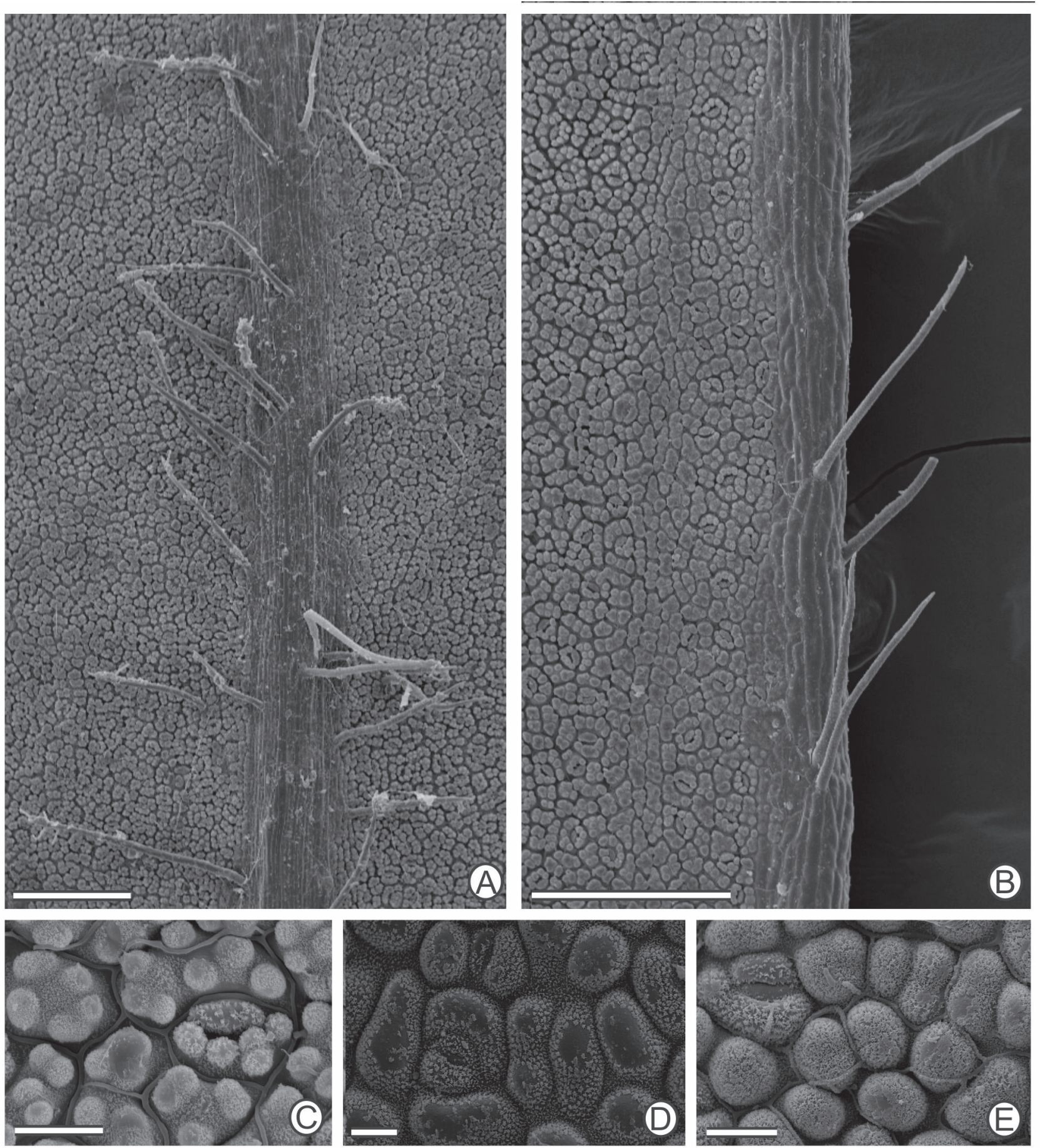

Figure 6. Scanning electron microscopy of the abaxial side of leaflets of species of Chamaecrista sect. Apoucouita. (A-C) C. adiantifolia var. pteridophylla. Note the non-secretory trichomes on the midvein (A) and (B) margins of the leaflets and the several domes per cell papillae (C). (D) C. polystachya and (E) C. hymenaeifolia displaying one dome per cell papillae. Bars = A-B, $200 \mu \mathrm{m}$; C-E, $20 \mu \mathrm{m}$.

taxa (Tab. 1), such as in C. bahiae (Fig. 7D) and $C$. eitenorum var. regana (Fig. 7E); sessile and concave in 19 taxa (Tab. 1) (Fig. 7F-K); urceolate in eight (Tab. 1); cupuliform and short-stalked in fifteen taxa (Tab. 1), such as in $C$. ensiformis var. ensiformis (Fig. 7L); cupuliform and stalked in 10 taxa (Tab. 1), such as in C. aspleniifolia (Fig. 7M); cupuliform and long-stalked in six taxa (Tab. 1), such as in C. subpeltata (Fig. 7N); patelliform and short-stalked in three taxa (Tab. 1); and patelliform and stalked and/or longstalked in four (Tab. 1), such as in C. compitalis (Fig. 7O). 

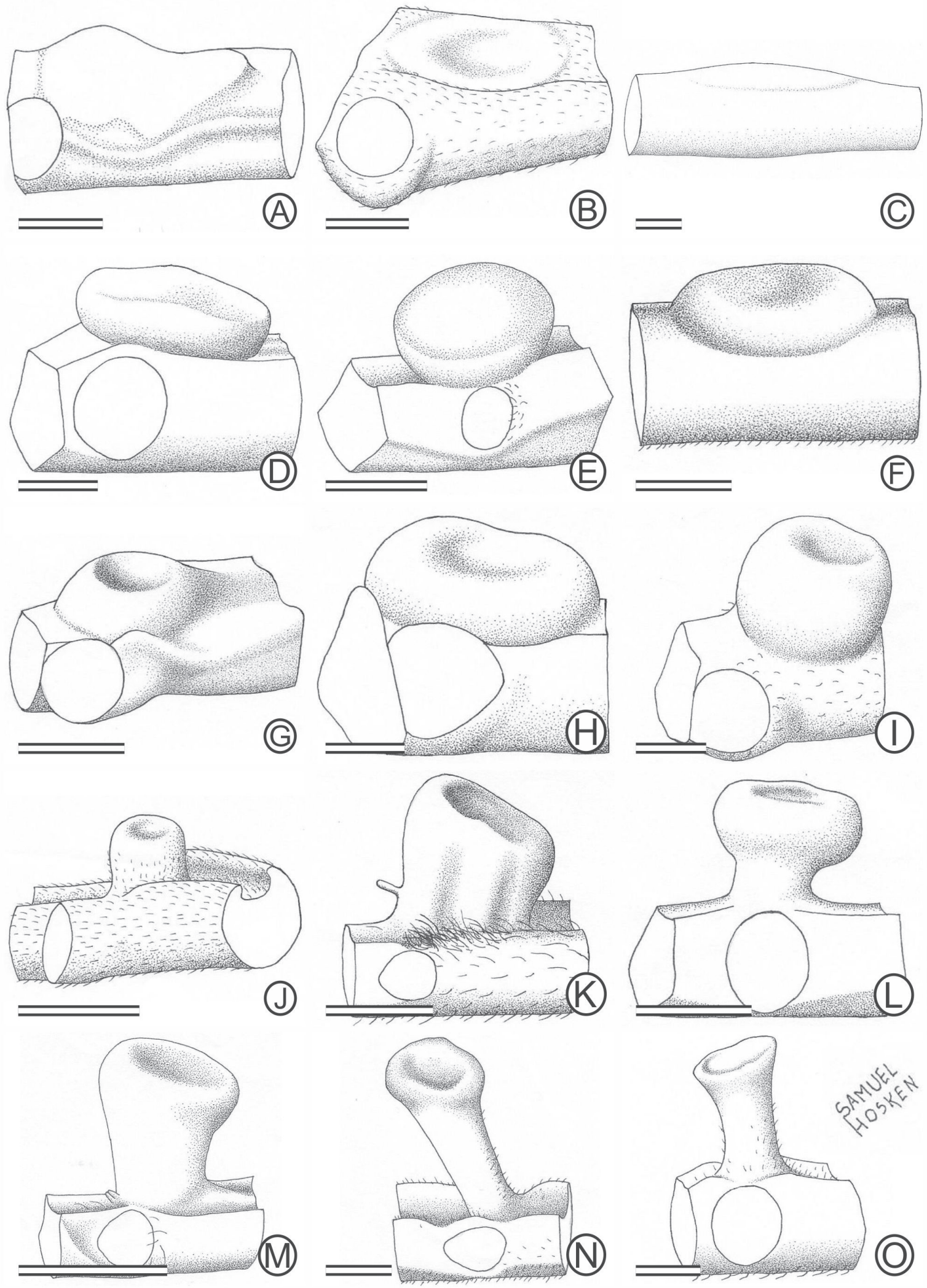

Figure 7. Extrafloral nectaries (EFN) on leaves of species of Chamaecrista sect. Apoucouita. (A) C. amabilis, (B) C. hymenaeifolia and (C) C. polystachya, EFN impressed. (D) C. bahiae and (E) C. eitenorum var. regana, sessile convex. (F) C. hymenaeifolia, (G) C. amabilis, (H) C. onusta, (I) C. ensiformis var. ensiformis, (J) C. xinguensis and (K) C. aspleniifolia, sessile concave. (L) C. ensiformis var. ensiformis, cupuliform short-stalked. (M) C. aspleniifolia, cupuliform stalked. (N) C. subpeltata, cupuliform long-stalked. (O) C. compitalis, patelliform stalked. Bars $=1 \mathrm{~mm}$. 
İtalo Antônio Cotta Coutinho, Juliana Gastaldello Rando,

Adilva de Souza Conceição and Renata Maria Strozi Alves Meira

\section{Identification key for Chamaecrista sect. Apoucouita}

An identification key for Chamaecrista sect. Apoucouita based on morphoanatomical characters of leaves:

1. Leaflets numerous 7-35 pairs; leaflets $5-35 \mathrm{~mm}$ long; petiole generally $<15 \mathrm{~mm}$ long (except in C. ensiformis var. plurifoliolata $12-25 \mathrm{~mm}$ long).....

2. Extrafloral nectary on the petiole proper and between/immediately below other pairs of leaflets; extrafloral nectary types variable; epidermis papillose at least on one side of leaflet blades; palisade parenchyma on the adaxial side at the midvein

3. Papillae with one dome per cell on the adaxial and abaxial epidermis; leaflets oblong-elliptic

3'. Papillae with several domes per cell on the abaxial epidermis only; leaflets oblong

4. Apex of leaflets obtuse to shallowly emarginate C. adiantifolia var. adiantifolia

4'. Apex of leaflets abruptly emarginate

C. adiantifolia var. pteridophylla

2'. Extrafloral nectary between/immediately below the basal pair of leaflets as well as other pairs of leaflets; extrafloral nectaries exclusively cupuliform; epidermis papillose on leaflet blades absent; epidermis papillose at least on one side of the leaflet blades absent; palisade parenchyma on the adaxial side at the midvein absent ............... 5

5. Petiole with pulvinus $12-25 \mathrm{~mm}$; leaflets ovate to narrowly-elliptic, base cuneate to obtuse, apex acute or acuminate...... C. ensiformis var. plurifoliolata

5'. Petiole with pulvinus 3-10 mm; leaflets oblong, base oblique, apex obtuse or retuse
6. Distributed in Bahia, Brazil
C. aspidiifolia
6'. Distributed in Maranhão, Brazil
C. subpeltata

1'. Leaflets less numerous 2-6 pairs (except in C. ensiformis var. plurifoliolata and C. xinguensis up to 10); leaflets 20-200 $\mathrm{mm}$ long; petiole $>12 \mathrm{~mm}$ long .

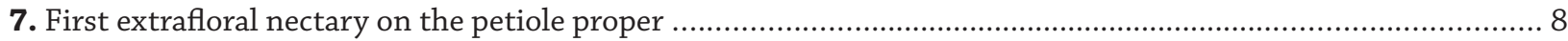

8. Extrafloral nectaries between/immediately below other pairs of leaflets; $6-10$ pairs of leaflets, ovate to narrowly ovate, base obtuse, apex acute or acuminate; papillae on the abaxial epidermis of the leaflet blades absent

C. xinguensis

8'. Extrafloral nectaries below other pairs of leaflets; 2-4 pairs of leaflets; leaflets asymmetrically ovate-elliptic or subsymmetrically obovate-suborbicular; papillae with one dome per cell on the abaxial epidermis of the leaflet blades present .....

... 9

9. Petiole with pulvinus 7-20 mm; extrafloral nectaries impressed only; leaflets asymmetrically ovate-elliptic short-acuminate and midrib curved; brochidodromous-craspedodromous venation with perimarginal veins of secondary type.

C. hymenaeifolia

9'. Petiole with pulvinus $20-40 \mathrm{~mm}$; extrafloral nectaries impressed, sessile flat/truncate/convex or sessile concave; leaflets subsymmetrically obovate-suborbicular, broadly obtuse or emarginate, and midrib straight; brochidodromous venation; perimarginal veins of secondary type absent C. polystachya

7'. Extrafloral nectary between/immediately below basal and other pairs of leaflets 10

10. Petiole with pulvinus $>50 \mathrm{~mm}$ long; sclereids in the mesophyll; leaflets obovate or oblong-obovate, base cuneate or narrowly cuneate, apex acuminate C. amorimii

10'. Petiole with pulvinus $<50 \mathrm{~mm}$ long; sclereids in the mesophyll absent .. 11

11. Petiole/rachis canaliculate, grooved or more or less marginate absent ................................................ 12

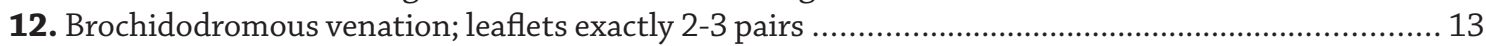

13. Leaflets usually 2 pairs of leaflets C. bahiae

13'. Leaflets usually 3 pairs of leaflets

C. duartei

12'. Eucamptodromous-brochidodromous venation; leaflets $2-6$ pairs .. 14

14. Leaflets 2-3 pairs, usually 2 pairs and broadly ovate with apex short-acuminate

C. negrensis var. negrensis

14'. Leaflets 3-6 pairs, usually 4-6 pairs and narrowly ovate with apex caudately long-acuminate ...... C. negrensis var. albuquerquei

11'. Petiole/rachis canaliculate, grooved or more or less marginate present .. 15

15. Stipules subulate-setiform over $1 \mathrm{~mm}$, commonly over $2 \mathrm{~mm}$; extrafloral nectary cupuliform or patelliform only, both stalked or long-stalked C. compitalis 15'. Stipules obsolete (not over $1 \mathrm{~mm}$ ), not observed or early caduceus; extrafloral nectary types variable .. 
16. Sessile to subssesile leaflets; blade of leaflets cordate or slightly so at base usually on either side present

17. Petiole/rachis canaliculate or grooved but the most distal segment of the rachis always marginate (winged) C. apoucouita or C. scleroxylon 17'. Petiole/rachis canaliculate or grooved but the most distal segment of the rachis never marginate (winged) 18

18. Leaflets exactly 2 pairs ................................................................. e. eitenorum var. regana 18'. Leaflets 3-4 pairs .................................................................. C. eitenorum var. albuquerquei

16'. Sessile to subssesile leaflets; blade of leaflets cordate at base usually on either side absent ...... 19 19. Leaves ample; petiole usually over $25 \mathrm{~mm}$; most distal pair of leaflets over $120 \mathrm{~mm}$... C. onusta 19'. Leaves smaller; petiole up to $25 \mathrm{~mm}$; most distal pair of leaflets up to $120 \mathrm{~mm}$ 20

20. Leaflets exactly 2 pairs C. amabilis

20'. Leaflets 3-8 pairs, rarely 2 C. ensiformis

taxa (Tab. 1), such as in C. bahiae (Fig. 7D) and C. eitenorum var. regana (Fig. 7E); sessile and concave in 19 taxa (Tab. 1) (Fig. 7F-K); urceolate in eight (Tab. 1); cupuliform and short-stalked in fifteen taxa (Tab. 1), such as in C. ensiformis var. ensiformis (Fig. 7L); cupuliform and stalked in 10 taxa (Tab. 1), such as in C. aspleniifolia (Fig. 7M); cupuliform and long-stalked in six taxa (Tab. 1), such as in C. subpeltata (Fig. $7 \mathrm{~N}$ ); patelliform and short-stalked in three taxa (Tab. 1); and patelliform and stalked and/or long-stalked in four (Tab. 1), such as in C. compitalis (Fig. 7O).

\section{Discussion}

The position and type of the extrafloral nectary (EFN) provided an important set of data that were very useful in the identification of taxa. EFN Position was especially useful in the recognition of $C$. adiantifolia, $C$. aspleniifolia, C. aspidiifolia, C. hymenaeifolia, C. onusta, C. polystachya, $C$. subpeltata and $C$. xinguensis since EFNs on the petiole proper could always be observed. EFN type was also quite important when there was little variation in shape, such as in C. hymenaeifolia, $C$. onusta and C. polystachya. For the remaining species, EFN type was generally quite variable, thereby limiting taxonomic usefulness. EFN position has previously been used successfully in the taxonomy of species of $C$. sect. Absus subsect. Baseophyllum (Conceição et al. 2008) as well as in Leguminosae (Lersten \& Brubaker 1987; Pascal et al. 2000; Marazzi et al. 2006; Melo et al. 2010) and other plant families (Keeler \& Kaul 1979; Oliveira \& Leitão-Filho 1987; So 2004; Weber \& Keeler 2013).

The presence of non-secretory trichomes is quite tricky to use as a character in the identification of taxa belonging to $C$. sect. Apoucouita. Non-secretory trichomes may or may not be present in many of the species, especially on leaflet blades, and they may even fall off, an issue that limits their taxonomic usefulness.

Having the vascular arrangement of the petiole similar to a siphonostele was common for all species of Chamaecrista sect. Apoucouita. This arrangement pattern, as well as the presence of accessory bundles (with accessory bundles in the wings, when such wings are present), have already been reported in the literature for Chamaecrista belonging to different sections (Metcalfe \& Chalk 1950; Coutinho et al. 2013; Francino et al. 2015). Although type XII and XIV of vascular arrangement of the petiole were exclusively observed in C. duartei and C. polystachya, this character has proven difficult to use in the identification of both species since other types of vascular arrangements in the petiole were also found.

Although the amount of sclereids in the cortex of the petiole varied, such character was not taxonomically promising but could be associated with the size of leaves instead. The presence of a greater number of sclereids in the petiole of larger leaves indicates that such cells may be involved in the mechanical support of leaves (Evert 2006). The arrangement of the vascular tissue in the petiole/rachis, as well as the presence of sclereids scattered among the cortex, may be useful in distinguishing vegetative branches of species of Chamaecrista sect. Apoucouita that resemble species of Inga when specimens are not flowering. For Inga punctata and Inga verna subsp. affinis, the transverse sections of the petiole/rachis also exhibits a continuous or interrupted ring of bundles, accompanied by accessory bundles in the wings (Metcalfe \& Chalk 1950; Arambarri et al. 2006). However, the main difference between the species of $C$. sect. Apoucouita and species of Inga is the presence of one/two large, accessory, centric, medullary bundle with central phloem and the lack of sclereids in Inga (Metcalfe \& Chalk 1950; Arambarri et al. 2006). Although more species of Inga should be checked to confirm if such an arrangement pattern of the vascular system is common for all species of the genus, the arrangement of the vascular tissue in the petiole/rachis is a promising character in the separation of C. sect. Apoucouita and Inga. Such differences can be easily observed in the field upon staining cross sections of the petiole/rachis with phloroglucinol, a die that stains lignified cell walls such as fibers and xylem cells (Johansen 1940).

Brochidodromous venation was found in all species except $C$. hymenaeifolia. Brochidodromous venation agrees with the pinnate venation described for the $C$. sect. 
Apoucouita (Irwin \& Rogers 1967; Irwin \& Barneby 1977; 1982). Craspedodromous-brochidodromous venation with perimarginal veins of secondary-type was unique to $C$. hymenaeifolia while eucamptodromous-brochidodromous venation was unique to $C$. negrensis. Druses associated with the vascular bundles and enlarged tracheids at the vein endings were also observed in all species of $C$. sect. Apoucouita and has already been reported for other species of Chamaecrista belonging to other sections (Coutinho et al. 2013; Francino et al. 2015;) in a way that such characters seem to be common for the genus.

All studied species had hypostomatic leaves, a character that is not widely spread in the genus, as other species from other sections (sect. Absus, Chamaecrista, Grimaldia and Xerocalyx) usually display amphistomatic leaves, except C. sect. Absus subsect. Baseophyllum with species having epistomatic leaves ( Coutinho et al. 2013; Francino et al. 2015). In Chamaecrista, hypostomatic leaves are common in species found in rain forests (C. sect. Apoucouita) while amphistomatic/epistomatic leaves are usually found in species from open sunny areas (sect. Absus, Chamaecrista, Grimaldia and Xerocalyx) which demonstrates that Chamaecrista display the typical ecological pattern of stomatal position described in the literature (Fahn \& Cutler 1992; Dickson 2000).

Paracytic laterocyclic stomata were present in all species of $C$. sect. Apoucouita and agrees with previous reports in Caesalpinioideae (Solereder 1908; Metcalfe \& Chalk 1950; Cowan 1981; Saheed \& Illoh 2010) and Chamaecrista (Francino et al. 2015).

Even though a few exceptions were observed, a straight or lightly sinuous outline of the anticlinal cell wall of the epidermal cells on the adaxial side and sinuous outline on the abaxial side was common for all species of $C$. sect. Apoucouita. This character is not very common in Chamaecrista since species tend to have a straight contour on both sides (Francino et al. 2015). The few exceptions observed regarding the outline of the epidermal cells may have been a result of the exposure of leaves to sun or shade; leaves exposed to sun usually have a straight outline while leaves exposed to shade display a sinuous outline (Pyykkö 1979). Since most of our material came from herbarium specimens, we do not know if they were exposed to sun or shade. Epidermal papillae were one of the most distinctive characters for species of C. sect. Apoucouita since only five species displayed them. Papillae on the adaxial and/or abaxial epidermal cells is not a common trait for Chamaecrista as they are usually restricted to the midvein (Francino et al. 2015).

The secretory epidermal cells observed are most probably mucilage idioblasts since the reddish-purple staining of the cells indicates the presence of pectins (O'Brien \& McCully 1981). The secretory idioblasts found in the mesophyll of species of $C$. sect. Absus subsect. Baseophyllum were revealed by histochemical analyses to be mucilage idioblasts
(Coutinho et al. 2013); these idioblasts also displayed a reddish purple color when stained with toluidine blue (Coutinho et al. 2013), similar to our results. Although Chamaecrista ensiformis var. ensiformis had already been anatomically studied Carvalho (1983-1985), the author failed to describe the presence of secretory idioblasts in the epidermis, even though a histochemical study was carried out. Epidermal mucilage idioblasts were also observed in other species of $C$. sect. Absus as well as $C$. sect. Grimaldia (Francino et al. 2015). Coutinho et al. (2013) suggests that mucilage idioblasts may represent an adaptation to aridity as Chamaecrista is a genus typically found in open sunny areas. However, species included in C. sect. Apoucouita are commonly found in the Amazon and Brazilian Atlantic forests, habitats well supplied with water. Nevertheless, some species are found in savannah-like areas, as is the case with $C$. aspidiifolia, $C$. polystachya, $C$ compitalis and $C$. eitenorum, an environment where the presence of mucilage in the epidermis could readily contribute to water retention.

Dorsiventral mesophyll and open arch collateral vascular bundles which may have 3-5 accessory bundles on the adaxial side were common for all species studied and had already been reported for other species of Chamaecrista (Metcalfe \& Chalk 1950; Coutinho et al. 2012; Francino et al. 2015). Considering only $C$. sect. Apoucouita, the presence of sclereids scattered in the mesophyll is a unique character for $C$. amorimii. Interestingly, $C$. amorimii has the largest leaves among the species of Chamaecrista, indicating that the presence of sclereids in the mesophyll is an important evolutionary character for this species, aiding in the mechanical support of its large leaves (Evert 2006).

Morphoanatomical characters of leaves proved to be a useful additional tool in the identification of species of Chamaecrista sect. Apoucouita, as such characters could be readily used to build an identification key. A number of other characters were shared by all species: the arrangement of the vascular system in the petiole/rachis and leaflets, dorsiventral mesophyll, mucilage idioblasts in the adaxial and abaxial epidermis, outline of the anticlinal walls of the epidermal cells and position and type of stomata. Even though such characters may be sparsely found in species of other sections of Chamaecrista (Coutinho et al. 2012; Francino el al. 2015), since they are present in all species of C. sect. Apoucouita, they may still be taxonomically promising by contributing to the consolidation of this group of species as a monophyletic section as demonstrated by Conceição et al. (2009).

Apart from the difference in the leaf apex, no other morphoanatomical characters that support the distinction of $C$. adiantifolia var. adiantifolia and C. adiantifolia var. pteridophylla were observed. Even with the difference in the leaflet apex, there are collections that may make us wonder which of the two varieties a specimen under consideration represents. This may be explained on the basis of the leaflet 
apexes. C. adiantifolia var. adiantifolia have leaflet apexes varying from obtuse to shallowly emarginated which may overlap with the emarginate or abruptly emarginate leaflet apexes of $C$. adiantifolia var. pteridophylla. Two collections that demonstrate this issue are Maguire et al. 41983, 02.XI.1957 (NY, SP, US) and Silva et al. 239, 03.XII.1985 (NY, US). The overlapping of this character in these collections leads us to question whether such taxa should be treated as two distinct varieties.

No remarkable morphoanatomical differences were observed between $C$. aspidiifolia and $C$. subpeltata that would support the distinction of these species. C. aspidiifolia usually displays a higher number of leaflets (9-13 pairs) than $C$. subpeltata (7-9 pairs), but these ranges clearly demonstrate that the number of leaflets may overlap. The geographic distributions of these two species seems to be the only justification for their separation at the species level. An effort to collect more specimens between the known distributions (i.e. states of Bahia and Maranhão, Brazil, for C. aspidiifolia and C. subpeltata, respectively) should be made in order to confirm whether there are populations with characters that are intermediate between the two species.

Although in our identification key does not separate $C$. bahiae and C. duartei properly separated, rising racemes have been widely used to distinguish $C$. duartei from $C$. bahiae; contemporary leaves at the end of hornotinous branchlets in the former, and old wood below contemporary leaves in the later (Irwin \& Barneby 1985). However, C. bahiae may also display racemes as observed in C. duartei (field observations) and vice versa, indicating that other characters should be found to distinguish these species.

Differing from Irwin \& Barnery (1977), we found that C. negrensis var. albuquerquei may have specimens with 6 pairs of leaflets instead of only 3-4. Although differences between the two varieties of $C$. negrensis were observed, we believe that they deserve a taxonomic review, especially because their leaflet and apex shape (broadly ovate with apex short-acuminate against narrowly ovate with apex caudately long-acuminate) may overlap. It seems that the number of leaflets would better distinguish these varieties of $C$. negrensis; $C$. negrensis var. negrensis with 2-3 pairs of leaflets and $C$. negrensis var. albuquerquei with 4-6 pairs.

Based solely on vegetative characters, $C$. apoucouita was not distinguished from C. scleroxylon. Irwin \& Barneby (1977) mentioned that in C. apoucouita the androecium is glabrous while in C. scleroxylon villosulous or velutinous. However, a shift of focus away from characters of pubescence and towards other characters has already been demonstrated by the same authors in the separation of two different taxa (i.e. the varieties included in C. adiantifolia) (Irwin \& Barneby 1977). Another difference pointed out between $C$. apoucouita and $C$. scleroxylon is that the former has a trunk that is deeply sulcate lengthwise while that of $C$. scleroxylon is sulcate. This character may be misleading, however, since the trunk of specimens is rarely represented or described in voucher material deposited in herbaria.

For C. eitenorum var. regana and C. eitenorum var. albuquerquei, the type of extrafloral nectary has been used as an additional character for their distinction (Irwin \& Barneby 1977). However, Coutinho \& Meira (2015) have already demonstrated that both varieties have the same types of extrafloral nectaries. Therefore, the type of EFNs should no longer be used to distinguish these varieties. Moreover, Irwin \& Barneby (1977) mentioned that the length of the leaf stalk is longer in C. eitenorum var. regana than in C. eitenorum var. albuquerquei, a character that is not surprising since the number of pairs of leaflets is higher in the later (3-4 pairs). Perhaps it is better that these varieties are described using only the difference in the number of leaflets. However, a greater number of collections of both varieties should be analyzed before amending taxon circumscriptions.

Unfortunately the three varieties included in $C$. ensiformis could not be distinguished base on the vegetative morphoanatomical analysis of the present study. Besides, floral characters are not constant for any one of the varieties (Irwin \& Barneby 1977). The characters used in the description of the varieties are sometimes overlapping, such as the number of pair of leaflets and pubescence of leaves ("thinly puberulente" or “ \pm densily pilosulous"). As shown in our results, pubescence is not a reliable character for the identification of such varieties, as it may vary equally for all of them. Only by having a petiole with a pulvinus smaller than $15 \mathrm{~mm}$ and 5-8 leaflets can C. ensiformis var. plurifoliolata be set apart. A revision of this species for a better circumscription of the varieties is needed.

\section{Conclusion}

Morphoanatomical characters of leaves provide an important set of data that may be used as diagnostic characters for some species of Chamaecrista sect. Apoucouita. The identification key presented herein is an important tool for species identification when only vegetative material is available. Our data provide evidence for the need of taxonomic re-evaluation of some taxa, especially varieties, since no anatomical differences were observed and some of the characters used in the circumscription of such taxa may overlap. When only vegetative material is available, species of $C$. sect. Apoucouita may be confused with the genus Inga. However, the arrangement of the vascular tissue and the presence of sclereids scattered among the cortex in the petiole/rachis seem to be promising characters that may aid the distinction of species of $C$. sect. Apoucouita and Inga. Moreover, a complete phylogenetic analysis of Chamaecrista, with the addition of the morphoanatomical characters common to all species of $C$. sect. Apoucouita, would confirm the usefulness of such data for taxonomy by providing data that could aid in demonstrating that this group of species as a monophyletic section. 


\section{Ítalo Antônio Cotta Coutinho, Juliana Gastaldello Rando, Adilva de Souza Conceição and Renata Maria Strozi Alves Meira}

\section{References}

Arambarri AM, Freire SE, Colares MN, et al. 2006. Leaf anatomy of medicinal shrubs and trees from gallery forests of the Paranaense Province (Argentina). Part 1. Boletin de la Sociedade Argetina de Botanica 41: 233-268.

Barneby RC. 1999. Increments to genus Chamaecrista (Caesalpiniaceae: Cassiinae) from Bolivia and from Atlantic and Planaltine Brazil. Brittonia 51: 331-339.

Camargo RA, Miotto STS. 2004. O gênero Chamaecrista Moench (Leguminosae-Caesalpinioideae) no Rio Grande do Sul. Iheringia 59: 131-148

Conceição AS, Queiroz LP, Lambert SM, Pereira ACS, Borba EL. 2008. Biosystematics of Chamaecrista sect. Absus subsect. Baseophyllum (Leguminosae-Caesalpinioideae) based on allozyme and morphometric analyses. Plant Systematics and Evolution 270: 183-207.

Conceição AS, Queiroz LP, Lewis GP, et al. 2009. Phylogeny of Chamaecrista Moench (Leguminosae-Caesalpinioideae) based on nuclear and chloroplast DNA regions. Taxon 58: 1168-1180.

Coutinho ÍAC, Francino DMT, Azevedo AA, Meira RMSA. 2012. Anatomy of the extrafloral nectaries in species of Chamaecrista section Absus subsection Baseophyllum (Leguminosae, Caesalpinioideae). Flora 207: 427-435.

Coutinho ÍAC, Francino DMT, Meira RMSA. 2013. Leaf anatomical studies of Chamaecrista subsect. Baseophyllum (Leguminosae, Caesalpinioideae): new evidence for the up-ranking of the varieties to the species level. Plant Systematics and Evolution 299: 1709-1720.

Coutinho ÍAC, Francino DMT, Meira RMSA. 2015. New records of colleters in Chamaecrista (Leguminosae, Caesalpinioidae s. l.): structural diversity, secretion, functional role, and taxonomic importance. International Journal of Plant Sciences 176: 72-85.

Coutinho ÍAC, Meira RMSA. 2015. Structural diversity of extrafloral nectaries in Chamaecrista sect. Apoucouita. Botany 93: 379-388.

Cowan RS. 1981. Caesalpinioideae. In: Polhill RM, Raven PH. (eds.).Advances in legume systematics. Part 1. Kew, Royal Botanical Gardens. p. 57-64.

Dantas MM, Silva MJ. 2013. O gênero Chamaecrista (Leguminosae, Caesalpinioideae, Cassieae) no Parque Estadual da Serra Dourada, Goiás, Brasil. Rodriguesia 64: 581-595.

Dickson WC. 2000. Integrative plant anatomy. San Diego, Academic Press.

Ellis B, Daly DC, Hickey LJ, et al. 2009. Manual of leaf architecture. Ithaca, Cornell University Press.

Evert RF. 2006. Esau's Plant Anatomy: Meristems, Cells, and Tissues of the Plant Body: Their Structure, Function, and Development. Hoboken, John Wiley \& Sons, Inc.

Fahn A, Cutler DF. 1992. Xerophytes. Berlin, Gebrüder Bomtraeger.

Francino DMT, Coutinho ÍAC, Dalvi VC, Azevedo AA, Conceição AS, Meira RMSA. 2015. Anatomical interpretations of the taxonomy of Chamaecrista (L.) Moench sect. Absus (Leguminosae-Caesalpinioideae). Plant Systematics and Evolution 301: 2087-2103.

Francino DMT, Sant'Anna-Santos BF, Silva KLF, Thadeo M, Meira RMSA, Azevedo AA. 2006. Anatomia foliar e caulinar de Chamaecrista trichopoda (Caesalpinioideae) e histoquímica do nectário extrafloral. Planta Daninha 24: 695-705.

Howard RA. 1979. The petiole. In: Metcalfe CR, Chalk L. (eds.) Anatomy of the dicotyledons. Vol I. Systematic anatomy of the leaf and stem. 2nd. edn. Oxford, Clarendon Press. p. 88-96.

Irwin HS, Barneby RC. 1977. Monographic studies in Cassia (Leguminosae: Caesalpinioideae). IV. Supplementary notes on section Apoucouita Bentham. Brittonia 29: 277-290.

Irwin HS, Barneby RC. 1979a. Two new Brazilian species of Chamaecrista Moench (Leguminosae: Caesalpinioideae). Brittonia 31: 464-468.

Irwin HS, Barneby RC. 1979b. Three new Brazilian species of Chamaecrista Moench (Leguminosae: Caesalpinioideae). Brittonia 31: 149-155.

Irwin HS, Barneby RC. 1982. The American Cassiinae: A synoptical revision of Leguminosae tribe Cassieae subtribe Cassinae in the New World. Memoirs of the New York Botanical Garden 35: 1-918.

Irwin HS, Barneby RC. 1985. A new arborescent Chamaecrista (Caesalpiniaceae: Cassiinae). Brittonia 37: 14-16.
Irwin HS, Rogers DJ. 1967. Monographic studies in Cassia (LeguminosaeCaesalpinioideae). II. A taximetric study of section Apoucouita. Memoirs of the New York Botanical Garden 16: 71-118.

Johansen DA. 1940. Plant microtechnique. New York, McGraw-Hill Book. Keeler KH, Kaul RB. 1979. Morphology and distribution of petiolar nectaries in Ipomoea (Convolvulaceae). American Journal of Botany 66: 946-952.

Lackey J. 1978. Leaflet anatomy of Phaseoleae (Leguminosae, Papilionoideae) and its relation to taxonomy. Botanical Gazette 139: 436-446.

Lersten NR, Brubaker CL. 1987. Extrafloral nectaries in Leguminosae: review and original observations in Erythrina and Mucuna (Papilionoideae; Phaseoleae). Bulletin of the Torrey Botanical Club 114: 437-447.

Lewis G. 2005. Tribe Cassieae. In: Lewis G, Schrire B, Mackinder B, Lock M. (eds.) Legumumes of the World. Kew, Royal Botanic Gardens. p. 111-161.

Luckow MA. 2002. Anatomical features of the leaves in the Dichrostachys group (Leguminosae, Mimosoideae) and their utility for phylogenetic studies. Systematic Botany 27: 29-40.

Marazzi B, Endress PK, Queiroz LP de, Conti E. 2006. Phylogenetic relationships within Senna (Leguminosae, Cassiinae) based on three chloroplast DNA regions: patterns in the evolution of floral symmetry and extrafloral nectaries. American Journal of Botany 93: 288-303.

Meira RMSA, Francino DMT, Ascensão L. 2014. Oleoresin trichomes of Chamaecrista dentata (Leguminosae): structure, function, and secretory products. International Journal of Plant Sciences 175: 336-345.

Melo Y, Machado SR, Alves M. 2010. Anatomy of extrafloral nectaries in Fabaceae from dry seasonal forest in Brazil. Botanical Journal of the Linnean Society 163: 87-98.

Metcalfe CR, Chalk L. 1950. Vol I Anatomy of the dicotyledons: leaves, stem and wood in relation to taxonomy with notes on economic uses. Oxford, Clarendon Press.

Metcalfe CF, Chalk L. 1979. Anatomy of the dicotyledons. Vol I. Systematic anatomy of leaf and stem with a brief history of the subject. 2nd. edn. Oxford, Clarendon Press.

Morris JB. 2012. Showy partridge pea [Chamaecrista fasciculata (Michx.) Greene] with potential for cultivation as a multi-functional species in the United States. Genetic Resources and Crop Evolution 59: 15771581.

O'Brien TP, McCully ME. 1981. The study of plant structure principles and selected methods. Melbourne, Termarcarphi Ptey. Ltd.

Oliveira PS, Leitão-Filho HF. 1987. Extrafloral nectaries their taxonomic distribution and abundance in the woody flora of Cerrado vegetation in Southeast Brazil. Biotropica 19: 140-148.

Pascal LM, Motte-Florac EF, McKey DB. 2000. Secretory structures on the leaf rachis of Caesalpinieae and Mimosoideae (Leguminosae): Implications for the evolution of nectary glands. American Journal of Botany 87: 327-338.

Pykkoö M. 1979. Morphology and anatomy of leaves from some woody plants in a humid tropical forest of Venezuela Guayana. Acta Botanica Fennica 112: 1-41.

Rando JG, Loeuille B, Pirani JR. 2013. Taxonomic novelties in Chamaecrista (Leguminosae: Caesalpinioideae) from Brazil. Phytotaxa 97: 17-25.

Rando JG, Pirani JR. 2011. Padrões de distribuição geográfica das espécies de Chamaecrista sect. Chamaecrista ser. Coriaceae (Benth.) H. S. Irwin \& Barneby, Leguminosae - Caesalpinioideae. Revista Brasileira de Botânica 34: 499-513.

Rando JG, Zuntini AR, Conceição AS, Berg C, Pirani JR, Queiroz LP. 2016. Phylogeny of Chamaecrista ser. Coriaceae (Leguminosae) unveils a lineage recently diversified in Brazilian campo rupestre vegetation. International Journal of Plant Science 177: 3-17.

Rizzini CT. 1976. Contribuição ao conhecimento das floras Nordestinas. Rodriguésia 28: 173

Saheed SA, Illoh HC. 2010. A Taxonomic study of some species in Cassiinae (Leguminosae) using leaf epidermal characters. Notulae Botanicae Horti Agrobotanici Cluj-Napoca 38: 21-27.

Smith FH, Smith EC. 1942. Anatomy of the inferior ovary of Darbya. American Journal of Botany 29: 464-471. 
So ML. 2004. The occurrence of extrafloral nectaries in Hong Kong plants. Botanical Bulletin of the Academia Sinica 45: 237-245.

Solereder H. 1908. Systematic anatomy of the dicotyledons. A handbook for laboratories of pure and applied Botany. Oxford, Clarendon Press.

Thiers B. 2016. Index Herbariorum: A global directory of public herbaria and associated staff. New York Botanical Garden's Virtual Herbarium. http://sweetgum.nybg.org/ih/. 5 Nov. 2015.

Torres DC, Lima JPMS, Fernandes AG, Nunes EP, Grangeiro TB. 2011. Phylogenetic relationships within Chamaecrista sect. Xerocalyx
(Leguminosae, Caesalpinioideae) inferred from the cpDNA trnE-trnT intergenic spacer and nrDNA ITS sequences. Genetics and Molecular Biology 34: 244-251.

Weber MG, Keeler KH. 2013. The phylogenetic distribution of extrafloral nectaries in plants. Annals of Botany 111: 1251-1261.

Wilkinson HP. 1979. The plant surface (mainly leaf). Part I. Stomata. In: Metcalfe CR, Chalk L. (eds.) Anatomy of the dicotyledons. Vol I. Systematic anatomy of the leaf and stem. 2nd. edn. Oxford, Clarendon Press. p. 97-117. 